\title{
Analysis of the Effectiveness of Buleleng District Government Policies Regarding the Collection of PBB-P2 During the COVID-19 Pandemic
}

\author{
Komang Intan Pradiska ${ }^{1}$ Krisanti Krisanti ${ }^{1, *}$ I Nengah Putra Jaya Suryanata ${ }^{1}$ \\ Gede Agus Indrawan ${ }^{1} \mathrm{Ni}$ Luh Gede Yastini ${ }^{1}$ I Gusti Agung Ayu Suryantini ${ }^{1}$
}

\author{
${ }^{1}$ Department of Economic and Accounting, Universitas Pendidikan Ganesha, Singaraja, Indonesia \\ *Corresponding author. Email : krisanti@undiksha.ac.id
}

\begin{abstract}
This research aims to find out 1) Forms of Application of Local Government Policies in Buleleng Regency related to the rural and urban property taxes collection, 2) Obstacles faced by Buleleng Regency Government in implementing Buleleng Regency Government Policies Related to Collecting The rural and urban property taxes, 3) Effectiveness of Buleleng Regency Local Government Policies Regarding The rural and urban property taxes Collection during the COVID-19 Pandemic.This researh used descriptive qualitative method. Data collection is done through the method of documentation techniques, interviews and literature studies. The data is then analyzed using data reduction, data presentation to drawing conclusions based on the specified theory. The results of the study show 1) The form of implementation of this policy is the abolition of the rural and urban property taxes administrative sanctions in 2020 and before. 2) Obstacles in implementing the policy, namely the declining ability of the public to pay, the apathy of the community in paying taxes. and Lack of dissemination of information regarding the Policy. 3) The policy is very effective in increasing the rural and urban property taxes revenue.
\end{abstract}

Keywords: Tax Policy, effectiveness, the rural and urban property taxes.

\section{INTRODUCTION}

COVID-19 is a disease that was originally endemic in China and is classified as zoonotic, which refers to a disease that is spread via humans and animals [1]. In response to the COVID-19 Pandemic in 2020, the Indonesian government implemented a policy of travel restrictions to and from countries that are in the COVID-19 pandemic's red zone of transmission. Economic losses have occurred across the country as a result of activity restrictions imposed by the COVID19 pandemic. COVID-19 has resulted in the country incurring losses as state revenues, particularly in the tax sector, have declined, while spending has increased as a result of dealing with emergency situations, providing social safety nets, dealing with sick people, deploying additional health personnel and personnel, and paying interest on new debts. [2] [3]

The negative impact of the COVID-19 pandemic was felt across all sectors, even causing a delay in the implementation of 11 different types of regional taxes in Buleleng Regency. The COVID-19 Pandemic in 2020 was one of the reasons the Buleleng Regency Government established a policy regarding local tax collection, as stated in Regent Circular No. $900 / 064.2 / 2020$, in order to manage and prevent the pandemic. This policy was implemented with the objective of increasing local tax revenues generated by the tax sector, particularly PBB P2.

According to [4] on Regional Taxes and Levies (UU PDRD), the Rural and Urban Land and Building Tax (PBB P2) is a source of revenue for autonomous regions whose collection authority is delegated to regional governments. The Regional Government stated that it would increase regional revenues from the P2 PBB sector through the Regional Finance and Revenue Management Agency of Buleleng Regency (BPKPD). The Rural and Urban Land and Building Tax (PBB P2) is one of the regional tax sectors that is the primary source of revenue for the Buleleng Regency government during the pandemic, given that a number of other tax sectors that were previously the primary source of revenue for the Buleleng Regency are said to be experiencing a slowdown in realization. BPKPD Buleleng Regency hopes that this policy will result in an increase in regional revenues and the achievement of the budgeted P2 PBB target in 2020 . Additionally, BPKPD hopes that this policy will increase public interest and awareness in complying with their tax obligations, as the policy provides tax relief to taxpayers. The Buleleng Regency tax will be 
implemented through the elimination of administrative sanctions or fines for P2 PBB arrears in 2020 and the preceding year. The policy on PBB P2 collection that provides relief in the form of the eradication of $\mathrm{PBB}$ P2 fines was initiated by the Buleleng Regency government during the COVID-19 Pandemic Period.

According to [5], government policy refers to decisions made by the government in a systematic manner with specific aims and objectives concerning the public interest. As a result, policy is a management process that encompasses the stages of planning, implementation, and supervision, such that the definition of policy serves as the foundation for implementing government, which is accomplished through a decision-making process by the authorities responsible for implementing government services. Policy is developed to safeguard and protect the community's interests in efficient and effective public services. As such, the policy serves as a vehicle for implementing the government's objectives.

According to data on the realization of Rural and Urban Land and Building Tax revenue (PBB P2) obtained from Buleleng Regency's Regional Finance and Revenue Management Agency (BPKPD), the target for the realization of the Rural and Urban Land and Building Tax revenue budget (PBB P2) in the second quarter (April - June) is lower than the first quarter. The target was lowered as a result of the government's recognition of revenue pressures caused by the COVID-19 pandemic in the previous quarter (Quarter I). Then, in the third quarter (July - August), the Buleleng Regency Government increased the budget target for Rural and Urban Land and Building Tax (PBB P2) revenue realization due to an increase in the previous quarter's realization of Rural and Urban Land and Building Tax (PBB P2) revenue. While the Rural and Urban Land and Building Tax (PBB P2) policy has been in effect since the second quarter, and revenue has increased each quarter, the Rural and Urban Land and Building Tax (PBB P2) has not met the target set in the third quarter. However, in the fourth quarter (October - December), the Rural and Urban Land and Building Tax (PBB P2) was said to be capable of exceeding the target set by the B. To ascertain the degree of success or achievement of a policy's objectives, it is necessary to evaluate the policy's effectiveness.

According to [6], effectiveness is a measure of an organization's success or failure to achieve its objectives. If an organization achieves its objectives, it is said to be operating effectively. Effectiveness in taxation refers to the relationship between the results of a tax levy and the potential or target of tax revenue. Effectiveness is a critical component or metric in the process of achieving the organization's previously established goals or targets. Something can be declared effective if the objective or target is met and in accordance with the previously established parameters (Soewarno, 2009). Considering this phenomenon, an assessment of the effectiveness of a tax policy is unavoidably necessary to determine the extent to which a policy can increase rural and urban land tax revenue realization during the COVID-19 pandemic.

In light of the above discussion, the objectives of this study are as follows: 1) To determine how local government policies were implemented in relation to the collection of Rural and Urban Land and Building Taxes (PBB P2) during the COVID-19 pandemic. 2) To determine the barriers to local government policies relating to the collection of Rural and Urban Land and Building Tax (PBB P2) in Buleleng Regency during the COVID-19 pandemic. 3) To determine the efficacy of Buleleng Regency's government policies on the collection of Rural and Urban Land and Building Tax (PBB P2) during the COVID-19 pandemic.

\section{METHOD}

According to the nature and purpose of this study, descriptive qualitative research methods are used. According to [7], a descriptive study was conducted to evaluate and explain the characteristics of the variables examined in a given situation. The objective of qualitative descriptive research is to use numbers to explain observed phenomena and to pay close attention to data collection and analysis. To ensure the data's validity, the researchers used triangulation. Triangulation, as defined by William Wiersma, is the process of comparing data from multiple sources at multiple points in time. Thus, there is triangulation of sources, triangulation of data collection techniques, and triangulation of time [8]. This study was conducted at Buleleng Regency's Regional Revenue and Finance Management Agency. The realization of PBB P2 in 2020 is as shown in Table 1. (BPKPD). The data collection technique used in this study began with documentation techniques and progressed to interviews with research informants, namely Mr. Ida Bagus War Wibawa SE, M.AP as Head of the Billing and Evaluation Section and Mrs. Putu Ayu Mira Kusuma Dewi, SE, M.AP as the Regional Tax Service's Head.

Submit a proposal and conduct a literature search. On the basis of the data collected, data reduction will be performed in order to isolate the data pertinent to the research. Additionally, data presentation is accomplished through the creation of narrative texts that include regularities, patterns, explanations, and meanings, as well as causal pathways. 
Table 1. Budget and Realization of PBB P2 in 2020

\begin{tabular}{|l|r|r|}
\hline Triwulan & \multicolumn{1}{|c|}{ Budget } & \multicolumn{1}{c|}{ Realization } \\
\hline I & 29.131 .907 .693 & 1.127 .509 .862 \\
\hline II & 9.750 .000 .000 & 2.853 .282 .355 \\
\hline III & 18.250 .000 .000 & 12.757 .102 .259 \\
\hline IV & 18.250 .000 .000 & 22.395 .521 .690 \\
\hline
\end{tabular}

Source: BPKPD, Processed data (2021)

The final process is data analysis, which places a greater emphasis on source research and reveals facts in plain, communicative language. Meanwhile, the effectiveness of local government policies in Buleleng Regency is determined using the effectiveness ratio prescribed by the Ministry of Home Affairs, Ministry of Home Affairs No. 690,900,327 in Adelina (2012):

$$
\begin{gathered}
\text { Effectiveness Formula }= \\
\frac{\text { Realization of } P 2 \text { PBB Revenues }}{P 2 \text { PBB Revenue Target }} \times 100 \%
\end{gathered}
$$

The interpretation of measuring the effectiveness of taxation can be seen in the table 2 .

\section{RESULTS \& DISCUSSION}

\subsection{Forms of Implementation of Buleleng} Regency Government Policies Regarding Rural and Urban Land Building Tax Collection (PBB P2) During the COVID-19 Pandemic Period

The COVID-19 pandemic is an unexpected occurrence that has resulted in a global economic slowdown. The pandemic of COVID-19 has paralyzed all sectors of the Indonesian economy, including the tax sector. As one of the strategies for increasing regional revenue from the tax sector, the Buleleng Regency Government implemented a policy as stated in Regent's Circular [9] on Regional Tax Collection Policies in the Context of Handling and Preventing the COVID-19 Pandemic. The Buleleng Regency Government provides the following policies to taxpayers through this policy.

1) Eradication of local tax administration penalties for the tax period March to December.

2) The removal is carried out in accordance with the administrative sanction of UN arrears prior to 2020, as determined by the Buleleng Regent.

3) Taxpayers for hotels, restaurants, entertainment, groundwater, billboards, nonmetallic minerals and rocks, and parking taxes may apply to the Regent cq Head of the Regional Finance and Revenue Management Agency (BPKPD) Buleleng Regency for the abolition of administrative sanctions and payment delays, as well as for tax arrears, prior to 2020, in accordance with applicable regulations.

4) For taxpayers who have ceased operations, inform the BPKPD of Buleleng Regency while continuing to meet their SPTPD reporting requirements.

Arrears of land tax for rural and urban buildings prior to 2020 are written off in accordance with the Regent's decision. This is done to raise public awareness and interest in meeting tax obligations, thereby ensuring that the tax sector's revenue target, particularly the rural and urban land and building tax (PBB P2), can be met during the COVID-19 pandemic.

The eradication of administrative sanctions in the form of fines on PBB P2 pursuant to the Regent's decree is one of the government's strategies and efforts to increase regional revenues in light of the slowdown in other tax sectors. Through the BPKPD, the Buleleng Regency Government believes that PBB P2 can still be boosted even after the COVID-19 pandemic occurred in 2020. According to the results of interviews with Mrs. Ayu Mira Kusuma Dewi, the head of the Regional Tax Service Sub-division at BPKPD Buleleng Regency in response to the new policy, she stated the following:

"Kami BPKPD Kabupaten Buleleng yang notabenya mengelola 11 jenis pajak daerah yang didalamnya ada pajak Hotel, restoran, hiburan dan termasuk PBB P2 juga mengalami dampak pengaruh dari Pandemi COVID-19. Pandemi ini terasa di pertengahan bulan ketiga yaitu bulan Maret Tahun 2020. Terkait dengan kebijakan, pemerintah daerah mengeluarkan Surat Edaran Bupati Nomor: 900/064.2/2020. Tentang Kebijakan Pemungutan pajak daerah Dalam rangka penanganan dan pencegahan Pandemi COVID-19. Khusus Untuk PBB P2, kita ada relaksasi pajak yang yaitu penghapusan sanksi administrasi atas tunggakan PBB sebelum tahun 2020. Biasanya batas terakhir pembayaran $P B B$ P2 itu bulan September. Namun apabila Wajib pajak membayar PBB lewat dari jatuh tempo, tentunya wajib pajak akan dikenakan denda senilai $2 \%$ begitu seterusnya denda bertambah setiap bulannya sampai di tahun ke 2, 48\% denda tersebut baru berhenti. Terhadap denda denda tersebutlah kita hapuskan. Berikutnya, jatuh tempo PBB P2 untuk tahun 2020, diperpanjang hingga desember 2020. Biasanya jatuh tempokan akhir September, tetapi melalui kebijakan ini Jatuh temponya hingga Desember, itupun dengan denda yang dihapuskan". 
Table 2. Interpretation of effectiveness values

\begin{tabular}{|c|c|}
\hline Percentage & Criteria \\
\hline$>100 \%$ & Very effective \\
\hline $90-100 \%$ & Effective \\
\hline $80-90 \%$ & Effective enough \\
\hline $60-80 \%$ & Less effective \\
\hline$<60 \%$ & Ineffective \\
\hline
\end{tabular}

"We, the BPKPD of Buleleng Regency, which in fact manages 11 types of regional taxes, which include hotel, restaurant, entertainment taxes and including PBB P2 have also experienced the impact of the COVID-19 pandemic. This pandemic was felt in the middle of the third month, namely March 2020. Regarding policies, the regional government issued a Regent Circular Number: 900/064.2/2020. Regarding Regional Tax Collection Policies in the context of handling and preventing the COVID-19 Pandemic. Especially for PBB P2, we have a tax relaxation which is the elimination of administrative sanctions for PBB arrears before 2020. Usually the last deadline for paying PBB P2 is September. However, if the taxpayer pays PBB past its due date, of course the taxpayer will be subject to a fine of $2 \%$ and so on, the fine increases every month until the 2nd year, $48 \%$ of the fine just stops. We will abolish these fines. Next, PBB P2 is due for 2020, extended until December 2020. Usually due at the end of September, but through this policy, the due date is until December, and even then with the fines removed."

Mrs. Putu Ayu Mirah Kusuma Dewi stated that in accordance with the Regent's decision, the administrative sanction in the form of a PBB P2 fine was repealed based on the policy stated in Circular No. $900 / 064.2 / 2020$. The same message was conveyed by Mr. Ida Bagus War Wibawa, Head of the Sub-Division for Regional Tax Collection in Buleleng Regency. S, E., and M.AP as quoted in the interview excerpt:

"Mengenai penerapan SOP, sebenarnya di sisi penagihan pajak tidak ada yang berubah dik, tetap saja, Hanya database yang kita rubah. Di sistem kita sudah takedown denda hingga yang ada hanya pokok pembayaran PBB P2. Jadi ketika sistem kita rubah berdasarkan surat edaran Bupati tersebut, tagihan di Bank maupun di tempat pembayaran yang telah disediakan hanya berupa pokok saja. Secara SOP tidak ada yang kami ubah"

"Regarding the implementation of SOPs, actually on the tax collection side, nothing has changed, still, only the database that we have changed. In our system, we have taken down fines so that there is only the principal payment for PBB P2. So when we change the system based on the Regent's circular, the bills at the bank or at the payment points provided are only in the form of principal. In the SOP, we don't change anything."

Although there is a new policy for rural and urban land taxes (PBB P2) collection during the pandemic, as stated in Regional Head of District Head Circular Letter No. 900/064.2/2020. The implementation in terms of tax collection has remained unchanged, as the Regent's decree provides that the abolition of PBB P2 administrative sanctions applies to all taxpayers registered in Buleleng Regency without exception. Thus preventing the Regional Government, in this case the BPKPD of Buleleleng Regency, from altering the SOP for tax collection. The Buleleng Regency Government responded to the policy by modifying the system in the form of a 'take down' of the PBB P2 fine by removing sanctions from the Buleleng Regency Finance and Revenue Management Agency's database (BPKPD).

Buleleng Regency's policy on P2 PBB collection is one of the regional government's efforts to increase regional revenue from the $\mathrm{P} 2 \mathrm{PBB}$ sector. As a means of implementing this policy, BPKPD, through UPTD spread throughout Buleleng Regency, aggressively provides door to door services to the community. According to Mr. Ida Bagus War, 'door to door' services are provided to avoid crowds and as an added service to the public. The Regent's Circular elicited a response from the community. Tax collectors also follow health protocols when providing services to the public at BPKPD and UPTD, such as maintaining a safe distance, wearing masks, and providing table blocking, in order to prevent the transmission of the COVID-19 virus between taxpayers and on-duty local tax collectors. Ayu Mira Kusuma Dewi also expressed this sentiment. To increase regional revenue on the PBB P2 side, the services provided by BPKPD through UPTD spread across Buleleng District are one of the key factors in achieving the P2 PBB revenue realization target during the COVID-19 Pandemic. The Buleleng Regency BPKPD's continuous services resulted in the realization of $\mathrm{P} 2 \mathrm{PBB}$ in the final 
quarter (IV) related to $\mathrm{P} 2 \mathrm{PBB}$ receipts during the 2020 pandemic period and increasing monthly.

\subsection{Barriers in the Implementation of Buleleng Regency Government Policies Regarding the Collection of Rural and Urban Land Building Taxes (PBB P2) During the COVID-19 Pandemic}

The government policies outlined in Regent's Circular No. 900/064.2/2020 regarding the collection of PBB P2 were largely implemented successfully. Mrs. Putu Ayu Mira Kusuma Dewi, the Regional Tax Service Subid's Head, stated this after reviewing data on the number of taxpayers, the majority of whom have made payments for SPPT spread during the 2020 COVID-19 Pandemic.

According to data obtained from Buleleng Regency's BPKPD as shown in Tabel 3, a total of 185,958 taxpayers paid for the scattered SPPT. In this case, BPKPD distributed 230,000 SPPT at the start of 2020 , implying that taxpayers paid 81 percent of the total SPPT distributed by BPKPD in 2020. However, BPKPD faces several obstacles in implementing the policy, including the fact that the percentage result from the calculation of the amount of SPPT payable in relation to the number of taxpayers who pay taxes does not reach $100 \%$. Naturally, the Regional Government, in this case the Regional Finance and Revenue Management Agency (BPKPD) of Buleleng Regency, faces obstacles in implementing this policy. Along with slowing the regional tax sector's realization, the COVID-19 pandemic has resulted in a decrease in the public's ability to pay, as the pandemic has a paralyzing effect on all economic sectors. Mr. Ida Bagus War Wibawa, the Regional Tax Collection Division's Head, stated in an interview that:

"Pandemi ini menyebabkan perekonomian hampir semuanya rubuh. Pekerja swasta rubuh dan banyak imigran kita yang berada di Denpasar pulang ke daerah. Hotel di Buleleng pun juga hampir sebagian besar tutup dan pegawainya dirumahkan. Jadi ya apalagi mereka bayar PBB ya, beli beras saja susah. Tapi tidak masalah, tujuan penerapan kita ingin meningkatkan penerimaan dan meningkatkan kesadaran masyarakat dengan penghapusan denda, kadang ada memang selentingan masyarakat yang mengatakan kepada kami, "pak de nak teke nagih pajak. Takonin malu, saya be ngidang meli roko sing? Saya be meli beras sing?" begitu. Dan itu saya hadapi, ya memang dalam penerapan kebijakan ini tidak 100\% mulus. Ya kadang ada juga masyarakat yang kita datangi tetapi malahan menanyakan bantuan pemerintah dan itu ada"

"This pandemic has caused almost the entire economy to collapse. Private workers fell and many of our immigrants who were in Denpasar returned to the area. Most of the hotels in Buleleng were also closed and their employees laid off. So yes, especially if they pay $\mathrm{PBB}$, it's difficult to buy rice. But it doesn't matter, the purpose of our implementation is to increase revenue and increase public awareness by eliminating fines, sometimes there are rumors that people tell us, "Pak de nak has to collect taxes. Takonin is embarrassed, I'm begging for meli roko sing? Can I buy rice sing?" so. And that I face, yes indeed in the implementation of this policy is not $100 \%$ smooth. Yes, sometimes there are people who we go to but instead ask for government assistance and it is there"

Constraints on BPKPD's ability to implement local government policies relating to the collection of $\mathrm{PBB}$, of course, include the taxpayers' ability to pay. The pandemic has exacerbated poverty and unemployment in the community, as many local taxpayers in Buleleng Regency have lost their jobs. as a result of the COVID19 Pandemic. Another factor impeding BPKPD from implementing local government policies as stated in Regent's Circular No. 900/064.2/2020 is the apathy of the populace, particularly PBB P2, despite the fact that taxes playa significant role and are increasingly relied upon for the benefit of development and government spending, in this case the local government of Buleleng Regency [10]

Apart from people's inability to pay taxes and the community's apathy toward the importance of complying with tax obligations, Mrs. Putu Ayu Mirah Kusuma Dewi stated that other obstacles confronting the Regional Government, in this case the Buleleng Regency BPKPD, are information related to tax relaxation, specifically the abolition of administrative sanctions in the form of fines. PBB P2, which is not known to all PBB P2 tax subjects who may be outside the Buleleng Regency area during the implementation of the policy.

Table 3. Total SPPT Payable and Number of Taxpayers Paying Taxes in 2020.

\begin{tabular}{|c|c|c|c|}
\hline Year & SPPT Taxpayer & Number & Percentage (\%) \\
\hline 2020 & 230.000 & 185.958 & $81 \%$ \\
\hline
\end{tabular}

Source; BPKPD, Data Processed in 2021 
Whereas in this case, the subject of PBB P2 is an individual or entity that actually has a right to the earth and/or benefits from it, and/or owns, controls, and/or benefits from the building. Mrs. Putu Ayu Kusuma Dewi, S.E., M.AP, stated this directly in the following interview excerpt:

"Yang namanya Pajak Bumi Bangunan pedesaan dan perkotaan kan menyangkut tentang bumi dan bangunan, terkadang ada masyarakat atau wajib pajak Buleleng yang tidak tinggal di Kabupaten Buleleng namun memiliki investasi berupa bumi dan bangunan di Buleleng, masyarakat (wajib pajak) tersebut belum mengetahui informasi ini meskipun dari kami pihak pemerintah daerah sudah menginformasikan mengenai kebijakan mengenai Surat Edaran Bupati No. 900/064.2/2020 melalui media masa, media sosial dan kita sudah gaungkan bahwa kita pemerintah kabupaten Buleleng melakukan relaksasi berupa penghapusan sanksi berupa denda terkait PBB P2 di tahun 2020. Kendala lainnya juga terkadang, masyarakat sudah mengetahui kebijakan ini, namun karena keterbatasan dana untuk melunasi kewajiban perpajakannya. Masyarakat tersebut tetap tidak membayar pajak karena keterbatasan tersebut"

"The name of the Rural and Urban Land Building Tax is about land and buildings, sometimes there are people or Buleleng taxpayers who do not live in Buleleng Regency but have investments in the form of land and buildings in Buleleng. from us the local government has informed the policy regarding the Regent Circular No. 900/064.2/2020 through mass media, social media and we have echoed that we, the Buleleng district government, are relaxing in the form of eliminating sanctions in the form of fines related to PBB P2 in 2020 Other obstacles are also sometimes, people already know this policy, but due to limited funds to pay off their tax obligations. The community still does not pay taxes because of these limitations."

Due to the difficulties encountered by the Buleleng Regency BPKPD in implementing Regional Government Policies relating to P2 PBB Collection, the BPKPD provided a solution in the form of delays and / or installment requests for P2 PBB payments, despite the fact that P2 PBB fines had been abolished in accordance with the Regent's decree contained in Regent's Circular No. 900/064.2/2020. Thus, the taxpayer is relieved of the obligation to pay all PBB P2 arrears. Additionally, in an effort to raise public awareness and reduce PBB P2 taxpayers' apathy, $\mathrm{BPKPD}$ has conducted socialization regarding local government policies, as stated in Regent's Circular No. 900/064.2.2020.

BPKPD provides socialization to ensure that residents of Buleleng Regency are aware that the policy was implemented during the COVID-19 Pandemic to alleviate the burden on the community, particularly PBB P2 taxpayers, in meeting their tax obligations, in light of the relaxation in the form of the elimination of administrative sanctions or fines for PBB P2 arrears in the previous year. Additionally, to increase public interest and awareness in paying taxes, the BPKPD collects taxes door to door in the related sub-districts via the UPTD, using a mobile vehicle called 'Yan Starpa'. Mobile car services and door-todoor services are two of BPKPD's efforts and strategies to intrigue public interest and awareness about the importance of complying with tax obligations during the COVID-19 Pandemic Period. The pandemic of COVID-19 has inadvertently compelled local governments to innovate and expand their services to the community.

To avoid crowds and make it simpler for the public to obtain information about PBB P2, the BPKPD established an online call center on the 'Whatsapp' application at the number $+62.813,6100.0046$, which is also accessible via the websitehttp://smartgov.bulelengkab.go.id:51086/logi $\mathrm{n}$. The public can obtain a variety of information on local tax services by contacting the Buleleng Regency BPKPD call center. The public can use this online service to print their own SPPT, as well as PBB P2 Tax arrears and other services.

\subsection{The Effectiveness of Buleleng Regency's Land Building Tax Collection Policies (PBB P2) During the Pandemic of COVID-19}

The Rural and Urban Land Building Tax (PBB P2) is one sort of tax that is regarded to have the potential to significantly contribute to Buleleng Regency's regional revenue. According to Buleleng Regency Regulation No. 5 of 2013, rural and urban land and building tax is a significant source of regional revenue used to finance local government administration and improve community services; therefore, it is necessary to regulate based on democratic, equity, justice, community participation, and accountability while taking regional potential into account. The Buleleng Regency Government's goal for enhancing regional earnings from the P2 PBB industry is to release Regent Circular No. 900/064.2/2020. Regional Government regulations on PBB P2 collection, as indicated in Regent's Circular No. 900/064.2/2020, were adopted 
in March but will take effect in April, or the Second Quarter of 2020.

Regional revenues increased to exceed the anticipated objective in 2020, based on the aggregation of $\mathrm{P} 2 \mathrm{PBB}$ revenue data from the second to fourth quarters as shown in Tabel 4. As the Head of Regional Tax Collection Bid, Mr. Ida Bagus War Wibawa, SE, M.AP said that no modification in target achievement occurred during the COVID-19 Pandemic Period. PBB P2 has been budgeted at Rp. $29,131,907,693$ at the start of 2020. However, as part of the process of defining the 2020 fiscal year's PBB P2 target, the PBB aim was reduced by $\mathrm{Rp}$. $18,250,000,000$ by the end of 2020. The March objective was established in light of the COVID-19 Pandemic phenomena, which slowed the implementation of the Regional Tax sector. A policy can be defined as the foundation for the government's execution gained through a decision-making process by the authorities responsible for the provision of services to the community. Policy is a tool for implementing the government's objectives. [5]. The Regional Government initiatives outlined in Regent Circular No. 900/064.2/2020 are credited with significantly raising regional revenues, particularly PBB P2, during the COVID-19 Pandemic. Mr. Ida Bagus War Wibawa expressed the following:

"Ditengah masa pandemi, tentu saja kebijakan tersebut efektive, buktinya ya bisa dilihat dari pertumbuhan penerimaannya, bahkan realisasinya lebih dari target yang ditentukan. Dengan SE (Surat Edaran) ini daya tempur kita (BPKPD) dalam melayani juga semakin baik."

"In the midst of a pandemic, of course the policy is effective, the proof can be seen from the growth in revenue, even the realization is more than the specified target. With this SE (Circular) our combat power (BPKPD) in serving is also getting better."

The Buleleng Regency Administration Policy on PBB P2 collection during the COVID-19 Pandemic has improved the performance and services of the BPKPD and UPTD, which are extensions of the regional government. While the COVID-19 pandemic has had a detrimental effect on several areas, including tax collection, the existence of the Pandemic Phenomenon and regulations aimed at preventing and managing COVID-19 present a positive side. The existence of tax relaxation, particularly PBB P2, instills optimism in the local government (BPKPD) of Buleleng Regency that the realization target of PBB $\mathrm{P} 2$ is capable of increasing regional revenues and meeting the target by the end of the year, such that in order to accomplish the policy's objectives, PBB P2 collection officers spread across UPTD in each District perform additional services in terms of policy dissemination.

To ascertain a policy's level of success, it is vital to assess the Buleleng Regency Government's policies on P2 PBB collection during the COVID-19 Pandemic. To determine the effectiveness of $\mathrm{P} 2 \mathrm{PBB}$ collection, the effectiveness ratio can be determined.

According to the Ministry of Home Affairs, the Ministry of Home Affairs No. 690,900,327 in Adelina (2012) was calculated using the following method from PBB P2 receipts during the 2020 COVID-19 Pandemic:

Effectiveness Formula $=$

$$
\begin{gathered}
\frac{\text { Realization of } P 2 \text { PBB Revenues }}{P 2 P B B \text { Revenue Target }} \times 100 \% \\
\frac{21.268 .011 .828}{18.250 .000 .000} \times 100 \%
\end{gathered}
$$

$$
117 \%
$$

Based on the results of the effectiveness measurement of Local Government Policies related to P2 PBB collection, which reached 117 percent, it can be concluded that Buleleng Regency Government Policies related to P2 PBB collections, as implied in Regent's Circular Letter no. 900/064.2/2020, are extremely effective in increasing regional revenues from the PBB P2 sector and in improving the performance and services of $\mathrm{P} 2 \mathrm{PBB}$ collection officers. This is because the conditions for interpretation are greater than $100 \%$ as shown in table 5, totaling $117 \%$. The efficacy level is determined based on the findings of an interview conducted with Mr. War Wibawa, Ka. Tax Collection Bag, and Mrs. Ayu Mira Kusuma Dewi, Head of Subid. BPKPD Tax Service for Buleleng Regency.

Table 4. Realization of P2 PBB Receipts in 2020 from Quarters II, III, and IV

\begin{tabular}{|l|l|l|l|}
\hline \multicolumn{1}{|c|}{ Quarter } & II & III & \multicolumn{1}{c|}{ IV } \\
\hline Budget & 9.750 .000 .000 & 18.250 .000 .000 & 18.250 .000 .000 \\
\hline Realization & 1.725 .772 .493 & 11.629 .592 .397 & 21.268 .011 .828 \\
\hline
\end{tabular}

Source: BPKPD, Data Processed in 2021 
Table 5. Effectiveness Value Interpretation

\begin{tabular}{|c|c|}
\hline Percentage & Criteria \\
\hline$>100 \%$ & Very effective \\
\hline $90-100 \%$ & Effective \\
\hline $80-90 \%$ & Effective enough \\
\hline $60-80 \%$ & Less effective \\
\hline$<60 \%$ & Ineffective \\
\hline
\end{tabular}

Source: Depdagri, Kepmendagri No. 690.900.327 In Adelina, Rina (2014)

According to [6], effectiveness is a measure of an organization's success or failure to fulfill its objectives. If an organization achieves its objectives, it is said to be operating successfully. In this example, the regional government strategy seeks to raise regional income in order to meet the COVID-19 Pandemic Period PBB P2 target. In accordance with Mardiasmo's theory of effectiveness,[11] states that something can be called effective if the aim or target is reached and in accordance with the previously established parameters. According to the results of interviews, effectiveness ratio measurements, and relevant theoretical theories about effectiveness, Regional Government Policies related to PBB P2 collection during the COVID-19 Pandemic can be said to be extremely effective as a form of government strategy for increasing regional revenues from the PBB sector. P2 in such a way that the realization target budgeted by BPKPD for the epidemic is met, if not exceeded.

\section{CONCLUSIONS}

Based on the findings of the aforementioned research studies, the following conclusion may be drawn: (1) The approach in which the Regional Government Policy on the Collection of PBB P2 is implemented, as specified in Regent Circular Letter No.900/064.2/1010, does not alter the standard operating procedure (SOP). Prior to the 2020 COVID19 pandemic, the BPKPD of Buleleng Regency collected P2 PBB. The only difference is that the BPKPD's P2 PBB collecting mechanism will be subject to administrative sanctions in the form of $\mathrm{P} 2$ PBB fines in 2020, whereas it was previously immediately eliminated, requiring taxpayers to make tax payments solely by paying the principal tax payable. Additionally, the Regional Government (BPKPD) collects PBB P2 in accordance with health guidelines when executing the policy. (2) The local government of Buleleng Regency faces numerous obstacles, including the low and declining ability of the populace to pay, apathy and a lack of public interest in paying the taxes they owe, and a lack of information dissemination regarding the Buleleng Regency Government's policies on PBB P2 collection, as stated in Regent's Circular No. 900/064.2/2020, which provides relief in the form of the abolition of administrative sanctions and / or fines for ar (3) As stated in Regent's Circular No. 900/064.2/2020, the Buleleng Regency Government's policy on PBB P2 collection is an extremely effective method for raising regional earnings from the PBB P2 sector. This was demonstrated during the COVID-19 Pandemic by the extremely high efficacy ratio of $\mathrm{P} 2 \mathrm{PBB}$ receipts, which exceeded the aim of 117 percent by the end of 2020. Which suggests it is really effective $(>100 \%)$.

Based on the findings of this study, the author makes the following recommendations: (1) For future researchers, it is expected that they will be able to dig up information about the implementation of local government policies related to the collection of $\mathrm{PBB}$ $\mathrm{P} 2$ in other regions and complete documents / evidence that support the findings of this study, thereby making the data obtained more valid and perfect. (2) The Regional Government and the Buleleng Regency BPKPD are expected to review and re-evaluate their decision not to extend the policy outlined in Regent's Circular No. 900/064.2/2020 regarding the abolition of $\mathrm{PBB} \mathrm{P} 2$ administrative sanctions, as the study's findings indicate that the policy is extremely effective. During the COVID-19 Pandemic, it was beneficial in promoting adoption of PBB P2.

\section{REFERENCES}

[1] Hanoatubun Silpa, "Dampak Covid -19 Terhadap Perekonomian Indonesia," J. Educ. Psychol. Couns., vol. 2, no. 11, pp. 146-153, 2020.

[2] W. Hadiwardoyo, "Kerugian Ekonomi Nasional Akibat Pandemi Covid-19," Baskara J. Bus. Entrep., vol. 2, no. 2, pp. 83-92, 2020, doi: 10.24853/baskara.2.2.83-92.

[3] W. S. Nursiam and V. V. Adhivinna, Analisis Efektivitas dan Kontribusi Penerimaan Pajak, vol. 3, no. 2. Terhadap Pendapatan Daerah Di Kabupaten Gresik, 2020. 
[4] Pemerintah Republik Indonesia, Undang Undang Republik Indonesia Nomor 28 Tahun 2009 Tentang Pajak Daerah Dan Retribusi Daerah. Indonesia, 2009.

[5] A. S. Hasibuan, "Peranan Ekologi Pemerintahan Dalam Meningkatkan Daya Saing Kebijakan Pemerintah Daerah," J. Kebijak. Pemerintah., vol. 2, no. 1, pp. 33-47, 2019, doi: 10.33701/jkp.v2i1.916.

[6] Mardiasmo, Otonomi dan manajemen keuangan daerah. Yogyakarta: Andi, 2012.

[7] U. da. R. B. Sekaran, Research Methods for Business: A Skill-Building Approach, Fifth. USA: Willey.

[8] Sugiyono, Metode Penelitian Kualitatif dan $R \& D$. Bandung: CV. Alfabeta, 2007.

[9] Bupati Buleleng, Surat Edaran Bupati Buleleng No. 900/064.2/2020 Tentang Kebijakan Pemungutan Pajak Daerah Dalam Rangka Penanganan Dan Pencegahan Pandemi COVID-19. Indonesia, 2020.

[10] H. Pancawati and Y. Nila, "Faktor-faktor yang mempengaruhi kemauan membayar pajak," Din. Keuang. dan Perbank., vol. 3, no. 1, pp. 126-142, 2011.

[11] N. Soewarno, "Corporate Social Responsibility: Motif Dan Risikonya," $J$. Ekon. dan Bisnis Airlangga (J E B A), vol. 19, no. 1, pp. 106-121, 2009, doi: 10.20473/jeba.V19I12009.4259. 